\title{
Comment on 'An investigation of the biogeochemistry of the uranium radionuclide in the munitions testing contaminated soil of Kirkcudbright, New Galloway, SW Scotland', by N. Kumar et al., J. Radioanal. Nucl. Chem., 290 (2011) 203-208
}

\author{
M. C. Graham
}

Received: 15 May 2012/Published online: 3 July 2012

(C) Akadémiai Kiadó, Budapest, Hungary 2012

I write to dissociate myself from the above paper on which I have been named as a co-author without either my knowledge or my permission. The latter would not have been given had I been approached by the corresponding author, N. Kumar (Department of Environment Studies, NorthEastern Hill University, Shillong, Meghalaya, India). For the record, my published work (2007-2011) arising from the UK NERC 'Depleted Uranium in the Environment' Programme (2005-2008) is listed below [1-5].

\section{References}

1. Oliver IW, Graham MC, MacKenzie AB, Ellam RM, Farmer JG (2007) Assessing depleted uranium (DU) contamination of soil, plants and earthworms at UK weapons testing sites. J Environ Monit 9:740-748

2. Oliver IW, Graham MC, MacKenzie AB, Ellam RM, Farmer JG (2008) Distribution and partitioning of depleted uranium in soils at weapons test ranges-Investigations combining the BCR extraction scheme and isotopic analysis. Chemosphere 72:932-939

3. Graham MC, Oliver IW, MacKenzie AB, Ellam RM, Farmer JG (2008) An integrated colloid fractionation approach applied to the characterisation of porewater uranium-humic interactions at a depleted uranium contaminated site. Sci Total Environ 404:207-217

4. Oliver IW, Graham MC, MacKenzie AB, Ellam RM, Farmer JG (2008) Depleted uranium (DU) mobility across a weapons testing site: isotopic investigation of porewater, earthworms and soils. Environ Sci Technol 42:9158-9164

5. Graham MC, Oliver IW, MacKenzie AB, Ellam RM, Farmer JG (2011) Mechanisms controlling lateral and vertical porewater migration of depleted uranium (DU) at two UK weapons testing sites. Sci Total Environ 409:1854-1866
M. C. Graham ( $\square)$

School of GeoSciences, University of Edinburgh,

Edinburgh EH9 3JN, Scotland, UK

e-mail: margaret.graham@ed.ac.uk 